\title{
Intensive technology of growth, complex processing of lambs flesh for meat products
}

\author{
Rashit Kazikhanov ${ }^{1}$, Saule R. Kazikhanova ${ }^{2 *}$, S. Seifullin Kazakh ${ }^{3}$ \\ 1, 2,3 Agro Technical University, Astana, Kazakhstan
}

\section{Key Words:}

Separately mammal method Exterior productive

Exotropia chain

Technological adequacy

Received: 8 December 2015

Accepted: 16 February 2016

Published: 22 February 2016

\begin{abstract}
The cheapest and ecologically pure meat can be got applying separately aspiration method in fat-tail lambs growing in the conditions of grassland keeping. The object of research is sheep of Kazakh fat-tail coarse-haired breed at "May" farm, JSC "Bastau", "Shaushen" farm breeding sheep of meat and fat breed with total number of 31000 heads. The experimental part of work was performed at livestock farm "May" May district of Pavlodar region during the period 1998-2009 at the Chair of S. Seifullin Kazakh Agro Technical University, at "Technology of meat, milk and food products" Chair of Shakarim Semey State University, Laboratory of Kazakh SRSIMMI (Scientific Research Structural Institute of Meat and Milk Industry) (Semey), Laboratories of RSRIMI (B.M Gorbatov's Russian Scientific Research Institute of Meat Industry). The results of research testify that lambs used to self-grazing and additional fertilizing intensively put on weight, grow well and develop and ewes grazing on grasslands very quietly and milking capacity increases from 1650 till 2074 gram per day. Carcass dressing proportions and fatness of lambs showed better conformation of high meat productivity and higher nutritious ness property and prospects using mutton for providing palatability diet products.
\end{abstract}

(C) 2016 The Author(s). Published by TAF Publishing.

\section{INTRODUCTION}

The cheapest and ecologically pure meat can be got applying separately aspiration method in fat-tail lambs growing in the conditions of grassland keeping. The results of research testify that lambs used to self-grazing and additional fertilizing intensively put on weight, grow well and develop and ewes grazing on grasslands very quietly and milking capacity increases from 1650 till 2074 gram per day. Intensive growth, complex estimation of fattail ram lambs5 meat production, lamb using (processing) and lamb meat, rational and perspective direction in the production of variety meat products.

Nowadays the level of meat production development both in our country and abroad makes new demands not only to control organization during technological process but to raw material control quality too. Changes inconsuming definition of "meat quality" and provision scheme are actively considered. Critical points of production process and measures of their prevention are defined according to standard conformity' for quality products control. Such approach is based on the principles of risk analysis concept and critical control points in the framework HACCP (Hazard Analysis Critical Control Points).

Thus defining of increasing effectiveness ways of meat raw processing should be based on information analysis about content, biological, physical and chemical properties, bi-

\footnotetext{
${ }^{*}$ Corresponding author: Saule R. Kazikhanova

†Email: saulekazihanova@mail.ru
} 
ological and food value of slaughter products providing close interrelation of united exotrofic chain: effective lamb's industry processing-consuming and adoption of nutrients containing in meat production by people. Such approach will allow purposively to fulfilling choice of dominant features of food and technological adequacy of meat raw material by which optimal variants can be defined their differentiation into different quality groups providing high effectiveness of processing and stability of quality finished products $[4,5$, 7 and 8].

Definition "Quality" in international standards is defined as "totality of product's characteristics in aggregate with possibilities of matching its revealed and required parameters" where quality can be defined as direct as indirect parameters. For increasing production profitability meat industry should thoroughly and accurately arrange the system of raw quality which should concentrate on the important consumers' aspects. Nowadays the main task of meat science includes the following:

- investigation of ways and means for meat and meat products quality improvement;

- necessity of meat raw complex research for processing industry on the level of molecule, cell and the whole animal's organism for deepening the basic mechanism depending on fat lipopexia and level of livestock post.

Market analysis of foreign countries such as Australia, New Zealand, Syria, France, Yugoslavia, Bulgaria and others testifies increased growth of lamb meat consumer. According to Imegeev's [1] data 2-3 ml. lambs of 100 days age are sent to slaughter yearly in Bulgaria which makes up 50\% from all mutton production.

Increased interest to the given kind of food product is connected with the quality of lambs' meat having high food value. By quantity and quality amino acid content it' close to "ideal" protein, has optimal correlation of proteins: fat, low calorie content and has delicate and succulent consistence. In addition lambs' meat differs with weak flavor and easily digests by the organism.

Low content of cholesterol in fat is the main feature of lamb meat. Such diseases as atherosclerosis and caries of teeth system are found rarely among people consuming most of all mutton and lambs' meat.

\section{MATERIALS AND METHOD}

The experimental part of work was performed at livestock farm "May" May district of Pavlodar region during the period 1998-2009 at the Chair of S. Seifullin Kazakh Agro Technical University, at "Technology of meat, milk and food products" Chair of Shakarim Semey State University, Laboratory of Kazakh SRSIMMI (Scientific Research Structural Institute of Meat and Milk Industry) (Semey), Laboratories of RSRIMI (B.M Gorbatov's Russian Scientific Research Institute of Meat Industry).

The object of research is sheep of Kazakh fat-tail coarse-haired breed at "May" farm, JSC "Bastau", "Shaushen" farm breeding sheep of meat and fat breed with total number of 31000 heads. Live weight, exterior features, meat and fat productivity, reproduction ability and milk production are studied at adult head of livestock.

Homogeneous selection and 'Bock-matting with the aim of getting progeny being up to quality of the following types at the period of accidental company among rams and ewes was made. It means that rams of normal type were flocked-matting with ewes of the same type and progeny became the given normal type. Ram-lambs were selected as the object of research because they are considered as the main meat contingent in sheep-breeding.

Growth of young animals was performed by adopted technology at the farm: lambing in April, from 20th day age growth is separately aspiration, weaning from dam at 4 month 
age. After weaning, thoroughbred and mongrel young animals were set for 2 month intensive fattening on natural grasslands adding 300 gram forage per head including in different proportions wheat, oats and barley.

The age of animal essentially influences to meat quality characteristics. First of al it is necessary to study age regularity and then try to find other factors which influence to meat quality.

Data received studying changes mutton quality against animals' age testifies that young animals' meat food value is higher than at adult sheep [2]. Thus the research was conducted at our work with a glance of character age of experimental young animals. The results of their appraisal were used at general estimation of animals.

1. Live weight was defined by individual weighting of experimental rams, dams, experimental lambs accurate within $0.5 \mathrm{~kg}$.

2. Exterior features were set by taking 8 main examples: height at withers, skew length of trunk, height at sacrum, depth of breast, width of chest, folding of chest, skew of metacarpus.

3. Ewes' reproductive ability was set with calculation of fecundated and yeaned ewes and obtained new born lambs. Ewes' milkness was set by lambs' live weight during 20 days with further calculation of general and average daily milkness.

4. Young animals' growth and progress were studied by lambs' live weight calculation at birth, 1, 2, 3 and drawback in 4 and 2 month fattening after drawback from ewes in one month age.

5. Meat productivity and meat quality were studies by control slaughter of 3-5 heads at birth, 2, 4, 6 and 16 months lambs. In this case carcass weight and fat tail, slaughter weight and output, morphological structure, meat coefficient, meat chemical structure and its calorie content.

6. Profiled and morphological structure of carcass by state standard 7596-81 "Mutton and goat's flesh dressing for retail trade".

7. Histological studying of the longest muscle spin, four head muscle of thigh and radial extensor muscle of wrist by Merkureva [3] method Chemical structure, biological and energy value of meat by medium tests of carcass flesh part as well as by the longest muscle of spin.

8. Functional, technological and culinary properties of meat by average sample of carcass flesh part and by the longest spin muscle.

9. Lipidic structure of meat by average sample of carcass flesh part on biochemical analyzer "Star -Fax" 1904 PLUS. Photo electrical calorimeter method is on the base of biochemical parameters.

\section{RESULTS}

Data of experienced lambs' live weight changes in milky period confirm high earliness. Fattail ram-lambs reached high live weight to the moment of weaning from dam in 4 month age: Unit x KG 42,7 kg or 65,7\% Edilbayevskyi, KPG x KG-39,1 kg or 71,1\% of Kazakh fattail semi coarse wool, KG x KG-41,6 kg or $69,3 \%$ of Kazakh fat-tail coarse wool adult dam's live weight. There with experienced ram - lambs' live weight to the moment of weaning increased: mongrel received from rams of Edilbayevskyi breed is 7,3.

Kazakh fat-tail semi coarse wool is 8,9; Kazakh fat-tail 8,9 times with average daily gain makes up 307,1, 289,1 and 307,7 g. Requirements of the standard of live weight were corresponded to Ivanov's et al. [4] statement: "Those ewes which lambs' average daily 
TABLE 1. The live mass of experimental lamb at the birth and beating from an ewe

\begin{tabular}{|c|c|c|c|c|c|c|c|}
\hline Breed Type & $\overline{\mathbf{N}}$ & $\begin{array}{l}\text { Wight } \\
\text { (Birth } \\
\text { Time) } \mathbf{X} \pm \mathbf{m} \\
\end{array}$ & Milk Quantity & Weight (Depriving from Ewes $\mathbf{X} \pm \mathbf{m}$ ) & Average Daily Gain, & Relative Gain\% & Growth Index $\%$ \\
\hline \multicolumn{8}{|c|}{ Traditional way of cultivation of lambs } \\
\hline KG x KG & 25 & $5,80 \pm 0,13$ & 120 & $36,30 \pm 0,60$ & 254,2 & 144,9 & 625,9 \\
\hline KKG $\times$ KG & 21 & $4,29 \pm 0,31$ & 120 & $33,78 \pm 0,31$ & 245,7 & 155,0 & 787,4 \\
\hline Ed x KG & 18 & $4,69 \pm 0,16$ & 120 & $35,85 \pm 0,52$ & 259,7 & 153,7 & 764,7 \\
\hline \multicolumn{8}{|c|}{ Separate \& sucking way of cultivation of lambs } \\
\hline KG x KG & 20 & $5,75 \pm 0,11$ & 120 & $40,0 \pm 0,75$ & 285,4 & 149,7 & 695,6 \\
\hline KKG x KG & 25 & $4,14 \pm 0,23$ & 120 & $36,59 \pm 0,42$ & 270,4 & 159,4 & 883,8 \\
\hline Ed x KG & 31 & $4,42 \pm 0,25$ & 120 & $35,85 \pm 0,96$ & 286,9 & 159,2 & 878,9 \\
\hline \multicolumn{8}{|c|}{ Separate \& sucking way of cultivation of lambs with top dressing } \\
\hline KG $\times$ KG & 20 & $5,85 \pm 0,10$ & 120 & $42,70 \pm 0,41$ & 307,1 & 151,8 & 729,9 \\
\hline KKG x KG & 16 & $4,41 \pm 0,12$ & 120 & $39,10 \pm 0,39$ & 289,1 & 159,5 & 886,7 \\
\hline Ed x KG & 21 & $4,68 \pm 0,10$ & 120 & $41,60 \pm 0,34$ & 307,7 & 159,5 & 888,8 \\
\hline
\end{tabular}

gain live weight at milky period makes up $260 \mathrm{~g}$. and higher, can be covered to earliness breeds" which are considerably exceeded standard requirements. Ram-lambs' slaughter weight at the age of 4-6 months has reached 23,8 -24,8 kg yield to 1,5 age wethers on $1,4-2,0 \mathrm{~kg}$ and by slaughter weight exceeded to $52,8-52,9 \%$. Such increasing of slaughter weight $(1,4-2,0 \mathrm{~kg})$ gained during 10 months by 1,5 age wethers don't justify overexposure till the next autumn.

Kazakh fat-tail semi coarse wool is 8,9; Kazakh fat-tail 8,9 times with average daily gain makes up 307,1,289,1 and 307,7 g. Requirements of the standard of live weight were corresponded to Ivanov's et al. [4] statement [4]: "Those ewes which lambs' average daily gain live weight at milky period makes up $260 \mathrm{~g}$. and higher, can be covered to earliness breeds" which are considerably exceeded standard requirements.

Ram-lambs' slaughter weight at the age of 4-6 months has reached 23,8 -24,8 kg yield to 1,5 age wethers on $1,4-2,0 \mathrm{~kg}$ and by slaughter weight exceeded to $52,8-52,9 \%$. Such increasing of slaughter weight $(1,4-2,0 \mathrm{~kg})$ gained during 10 months by 1,5 age wethers don't justify overexposure till the next autumn.

Thus it's important and our experience confirms that maximal using of biological peculiarities of fat-tail sheep breeding-premature is the large reserve of lambs' production and quality improvement.

TABLE 2 . Relative lethal indicators of experimental mail lamb of different age in comparative aspect with indicators of 16 months of an edilbayevsky ram

\begin{tabular}{|c|c|c|c|c|c|c|c|c|c|c|c|c|c|}
\hline \multirow[t]{2}{*}{ Age, Month } & \multirow[t]{2}{*}{ Breed Type } & \multicolumn{2}{|c|}{ The Preslaughter Mass } & \multicolumn{2}{|c|}{ The Mass of Ink with a Fat Tail } & \multicolumn{2}{|c|}{ Mass of a Fat Tail } & \multicolumn{2}{|c|}{ Mass of Internal Fat } & \multicolumn{2}{|c|}{ Lethal Weight } & \multicolumn{2}{|c|}{ Lethal Exit } \\
\hline & & кг & $\%$ & кг & $\%$ & кг & $\%$ & кг & $\%$ & кг & $\%$ & кг & $\%$ \\
\hline \multirow[t]{3}{*}{ birth } & KG x KG & 4,5 & 8,0 & 2,25 & 8,6 & 0,15 & 4,6 & - & - & 2,25 & 8,6 & 50,0 & 107,5 \\
\hline & KKG x KG & 4,0 & 7,1 & 1,9 & 7,3 & 0,10 & 3,1 & - & - & 1,90 & 7,2 & 47,5 & 102,1 \\
\hline & Ed $x$ KG & 5,8 & 10,3 & 2,90 & 11,1 & 0,16 & 4,9 & 0,06 & 40,0 & 2,96 & 11,3 & 51,0 & 109,7 \\
\hline \multirow[t]{3}{*}{2} & КГ х КГ & 28,0 & 49,7 & 12,7 & 48,7 & 2,50 & 76,9 & 0,42 & 280,0 & 13,12 & 50,1 & 46,8 & 100,6 \\
\hline & КПГ х КГ & 26,0 & 46,2 & 11,4 & 43,8 & 2,10 & 64,6 & 0,44 & 293,3 & 11,84 & 45,2 & 45,5 & 97,8 \\
\hline & ЕД $\mathrm{x}$ КГ & 29,5 & 52,4 & 14,0 & 53,7 & 2,70 & 83,3 & 0,50 & 333,3 & 14,50 & 55,3 & 49,1 & 105,6 \\
\hline \multirow[t]{3}{*}{4} & КГ х КГ & 40,6 & 72,1 & 20,0 & 76,8 & 3,50 & 107,7 & 0,50 & 333,3 & 20,50 & 78,2 & 50,5 & 108,6 \\
\hline & КПГ х КГ & 37,2 & 66,1 & 17,1 & 65,6 & 3,10 & 95,4 & 0,54 & 360,0 & 17,64 & 67,3 & 47,4 & 101,9 \\
\hline & ЕД х КГ & 41,5 & 73,7 & 21,4 & 82,1 & 3,70 & 113,8 & 0,65 & 433,3 & 22,05 & 84,2 & 53,1 & 114,2 \\
\hline \multirow[t]{3}{*}{6} & КГ х КГ & 45,1 & 80,1 & 23,1 & 88,7 & 4,0 & 123,1 & 0,72 & 480,0 & 23,83 & 90,9 & 52,8 & 113,5 \\
\hline & КПГхКГ & 42,2 & 74,9 & 19,5 & 75,0 & 3,30 & 101,5 & 0,60 & 400,0 & 20,1 & 76,7 & 47,6 & 102,4 \\
\hline & ЕДхКГ & 46,0 & 81,7 & 24,0 & 92,1 & 4,60 & 141,5 & 0,80 & 533,3 & 24,8 & 94,6 & 53,9 & 115,9 \\
\hline
\end{tabular}


Size and form of fat-tail in lambs' production plays important role which is essentially exterior-productive, constitutional feature of fat-tail sheep. It serves as a resource of energy for supporting of organism at unfavorable periods of year. Thanks to fat - tail sheep are able to withstand long-term malnutrition.

Ewes at the period of in-lamb use the reserve of fat for the growth and development of fetusŝupporting of normal feeding and physiological function of organism. At our research experimental ram-lambs had medium size and small size of fat-tail with the mass at birth 0,10 up to $0,16 \mathrm{~kg}$ with output of $2,5-3,3 \%$ to live weight. Size of ram-lamb and fat -tail increase with up growth, meat increasing and fat-tail size reaches up to 2,20-2,70 kg with output of $8,1-9,1 \%$ to the age of 2 months or increases from the birth till the age of 2 months from 16,8 up to 21 times, to the age of 4 months mass of fat-tail increases up to $3,10-3,70$ or quintuple up to 20,1-37 times. This argues about compensation of inchoate extent and size of fat-tail in embryonic period at the expense of fast precocious appearing at milk period. To the age of 6 months the mass of fat-tail reaches to 3, $30-4,60 \mathrm{~kg}$ with the output of 7,8 till $10 \%$ of preslaughter mass. Size of fat-tail was not paid attention in selection of animals because of standard absence to lambs' fat-tail size. It's a pity but nowadays current standards of fat-tails' size doesn't take into account in defining quality of carcass. In future it is well - handled to make selection in the direction of animals' storage with large size of fat-tails in connection with increasing of precociousness5 lambs' meat quality7 as well as increasing assortment of lambs' meat products especially halyal.

\section{CONCLUSION}

Protein quality of mutton index, amino acid and, lipid content of muscle tissue was examined by jointly with scientific staff of SRSIMMI (Scientific Research Structural Institute of Meat and Milk Industry), "Te chnology of meat, milk and food products" Chair of Shakarim Semei State University, RSRIMI (B.M Gorbatov's Russian Scientific Research Institute of Meat Industry). According to Кювье [5] calculation of protein quality index is the best spread method of protein quality estimation.

Amino acid content of protein is the main index on the base of which it can be predetermined about meat biological value of different brans of muscle tissue including 18 amino acids among them 8 irreplaceable. The sum of free amino acids in lambs' meat is fluctuated from 28,55 up to 20,57 gram and content of irreplaceable amino acids makes up from 13.08 up to 9,05 gram/100 gram of protein.

TABLE 3. Protein quality index of mutton $\mathrm{n}=36$

\begin{tabular}{llll}
\hline \hline Age, Months & Tryptophane, mg \% & Oxiprolin, mg \% & Protein Quality Index \\
\hline 4 & $224,61 \pm 4,22$ & $129,62 \pm 1,10$ & $1,7 \pm 0,1$ \\
6 & $311,63 \pm 5,32$ & $122,03 \pm 1,21$ & $2,5 \pm 0,2$ \\
8 & $323,21 \pm 6,77$ & $109,80 \pm 1,12$ & $2,9 \pm 0,2$ \\
12 & $334,12 \pm 5,44$ & $107,74 \pm 1,06$ & $3,1 \pm 0,2$ \\
\hline \hline
\end{tabular}

It's worth to point out that lamb at the age of 4 months $(1,7)$ is the most valuable in food attitude. At other ages increasing of protein quality index especially at the age of 12 months $(3,1)$ is overseen. Lambs' and young animals' meat of fat - tail sheep grown in the conditions of grasslands, the content of copper is in 24 times, lead in 1,25 times, zinc in 16 times less than normative data and toxic elements as mercury, arsenic, cadmium and pesticides didn't reveal. Research of lambs' toxic safety at the age of 4 and 6 months are up to qualities that's why sheep's slaughter is recommended at these age periods.

In whole it's worth paying attention that there is cholesterol in young animals' meat 
at the process of growth. Four month milky lambs' low level of cholesterol can be considered as favourable moment from the point of perspective processing of meat raw for the production of meat products with high food quality.

TABLE 4 . The content of cholesterol, $\alpha, \beta$ - Lipoproteidas in mutton of various age, $\% \mathrm{mg}$

\begin{tabular}{llll}
\hline \hline Age, Months & \multicolumn{3}{c}{ Biologically Active Agents } \\
\hline & General Cholesterol & $\begin{array}{l}\text { Lipoporoteida of the } \\
\text { High Density (LHD) }\end{array}$ & $\begin{array}{l}\text { Lipoporoteida of the } \\
\text { Low Density (LLD) }\end{array}$ \\
\hline 4 & $58,12 \pm 1,87$ & $0,95 \pm 0,72$ & $3,97 \pm 0,85$ \\
6 & $103,23 \pm 3,07$ & $0,94 \pm 0,65$ & $3,93 \pm 0,74$ \\
8 & $121,17 \pm 2,80$ & $0,92 \pm 0,57$ & $2,97 \pm 0,63$ \\
12 & $122,34 \pm 2,91$ & $0,89 \pm 0,48$ & $2,47 \pm 0,52$ \\
\hline \hline
\end{tabular}

On the base of above mentioned research the standard of the Republic of Kazakhstan "Lambs for slaughter. Lambs meat. General technical conditions" was developed [6]. Standard introduction of objective measurable criterions of Iambs estimation and received meat by food and technological adequacy (predetermined level of equivalence of technological processes to the specificity of processed raw quality) gives possibility to spread meat efficiently and rationally according to its quality to processing of sausages, semiprepared meat products, tinned food and smoking foods.

Being founded on the received experimental data it's worth mentioning that intensive growing, complex estimation of meat productivity of fat-tail young rams, using (processing) of lambs' meta and young rams are rational and perspective direction at production of meat products of stock.

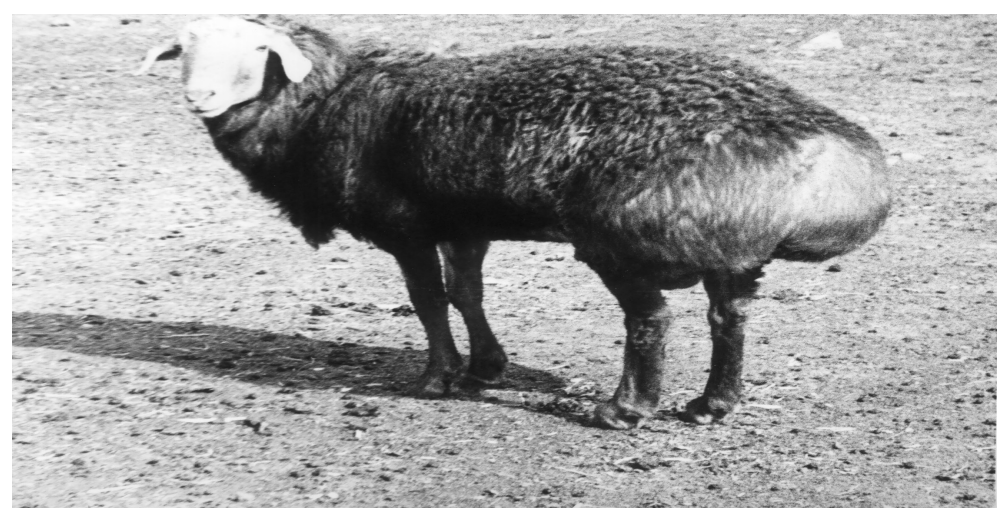

Live weight-102kg, wool productivity 3,5kg. klass elita

FIGURE 1. Grandmail of first line 


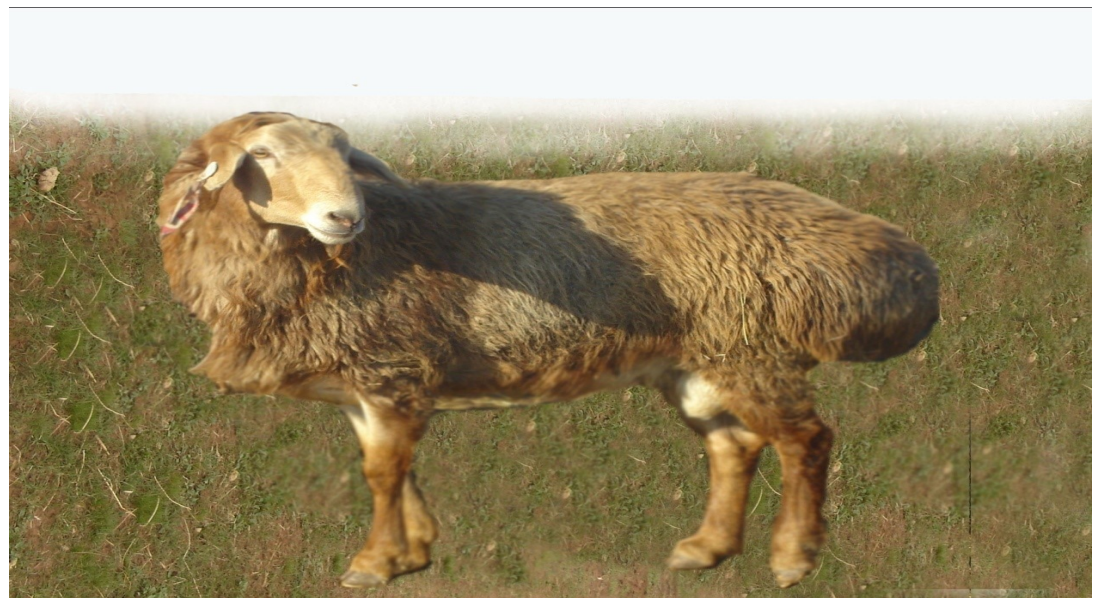

Weight-98кг, wool producrivity- 3,0кг, long of wool-11, 5см,пуха-7, 2см. Klass elita

FIGURE 2. Ram of first line no. 2708

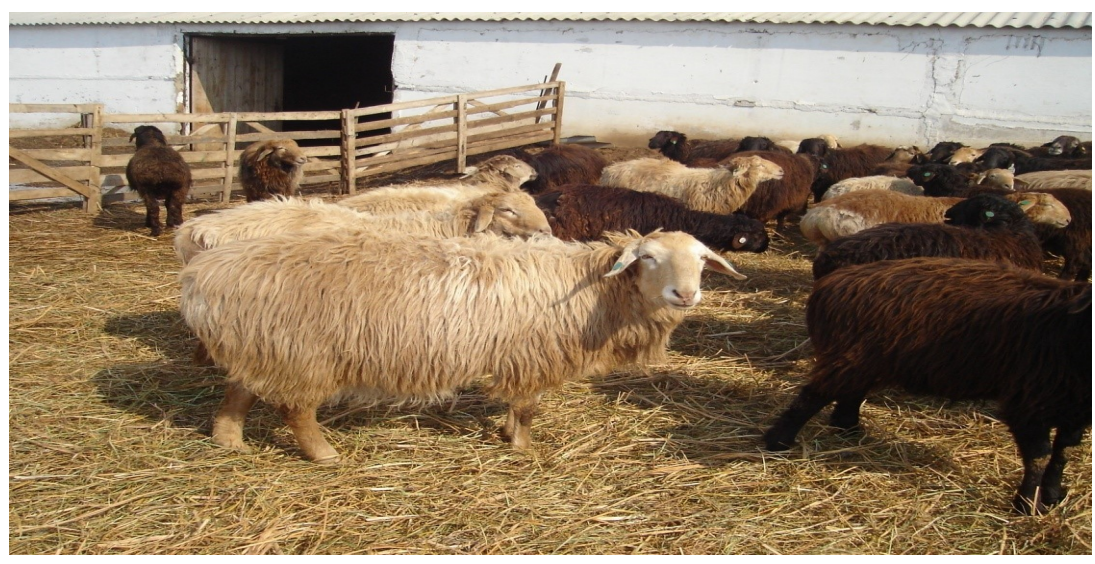

FIGURE 3 . Kazakh fat-tail coarse-haired breed of JC

The object of research is sheep of Kazakh fat-tail coarse-haired breed of JC "Bastau", "Shaushen" farm breeding sheep of meat and fat breed with total number of 31000 heads There is grandmother of the First Line №03406, weight -74кг, wool productivity- 3,2кг. Klass Elita

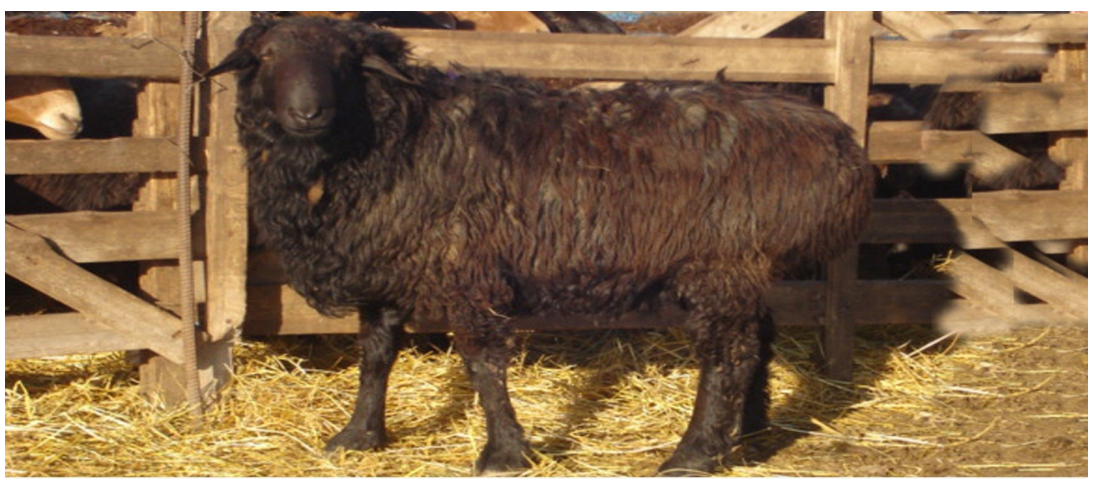

Рис. 1 Баран-продолжатель № 35010 из линии 31030. Живая масса 98 кг. Настриг шерсти - 3,7 кг.

FIGURE 4. The ram of the second line 


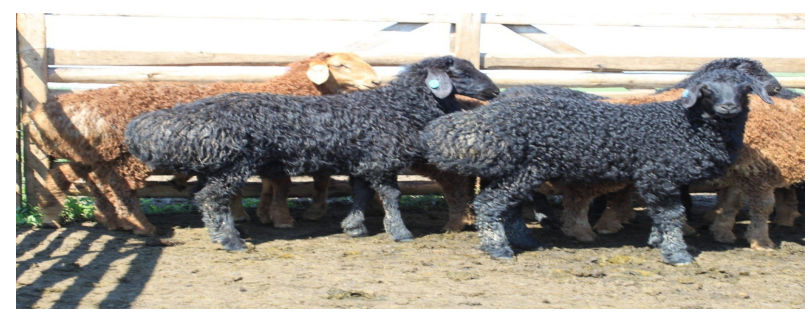

FIGURE 5 . There is a group of 2 month fat-rumped lambs at the second line

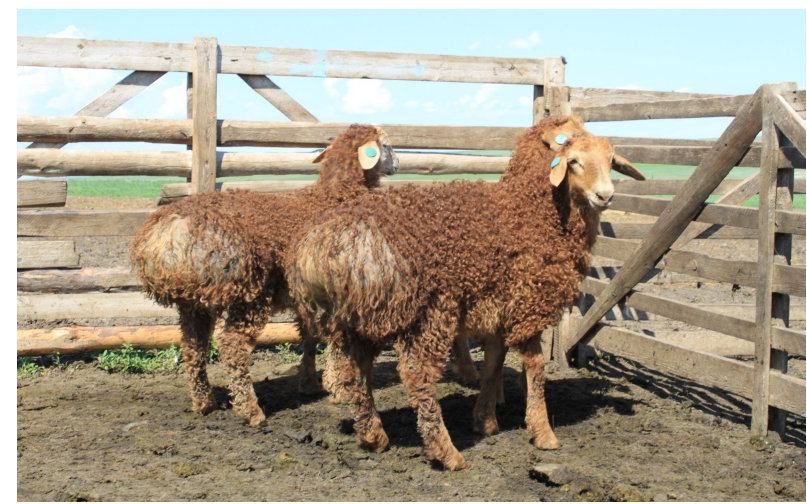

FIGURE 6 . There is a group of 2 month fat-rumped lambs at the first line

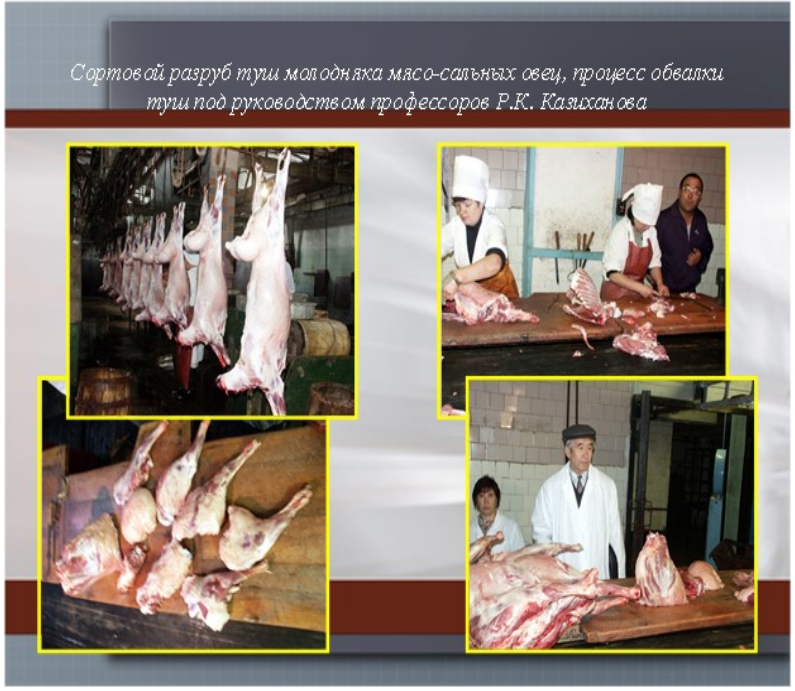

FIGURE 7 . High quality cutting of carcasses of sapling/pl of meat \& lard sheep process of causing to/fall of carcasses under the direction of professor R. Kazikhanov 


\section{REFERENCES}

1. Imigeev YI. Chicken meat production in Bulgaria. 1976.

2. Chirvinski NP. Chirvinsky NP selected works. 1949. 3. Merkureva EK. Merkuryeva EK biometrics in plant breeding and genetics of farm animals. 1970.

3. Ivanov MF, Kiverin AD. Effect of the composition of the combustible mixture on the development of flame front instability. Russian Journal of Physical Chemistry B. 2010; 4(1): 110-116.

4. Кювье. Ivanov MF compositions. 1939.

5. Cuvier J. Relationship between the selection and the law of correlation. n.d.

6. H. Mohebalian and So. Alizadeh. The antimicrobial activity of green tea extract against the major food born bacteria. Journal of Advances in Health and Medical Sciences. 2016; 2(2): 54-60.

7. Jarjusey F. Consumers' awareness and knowledge about food waste in Selangor, Malaysia. International Journal of Business and Economic Affairs. 2017; 2(2): 91-97.

— This article does not have any appendix. - 